\title{
STRATEGI COPING WANITA PEKERJA FORMAL DAN INFORMAL DALAM MENGATASI KONFLIK PERAN GANDA DI BANYUMAS
}

\author{
Retno Dwiyanti ${ }^{1}$, Pambudi Rahardjo ${ }^{2}$ \\ ${ }^{12}$ Fakultas Psikologi Universitas Muhammadiyah Purwokerto \\ retnodwiyanti@ump.ac.id
}

\begin{abstract}
This study aims to determine differences in duel roles conflict between formal workers women with informal workers women, and to obtain findings about coping strategies in women workers formal and informal women workers in the face of conflict. The method used in this research is a descriptive study with a mix method approach. Retrieving data using observation and interviews. The results showed that there was no significant difference between the conflict of the dual role of working women formal with informal women workers. Conflict on the dual role of working women is higher than the formal dual role conflict on women informal workers. Coping strategies was used by women of formal workers in the form of Emotion Based among others: control emotions, sometimes annoyed with the kids, go with family, venting problems with co-workers, and in the form of problem-based include: control emotions, regret because sometimes irritated with children, go with family, wreak problems with coworkers.
\end{abstract}

Keywords : conflict, coping strategies, formal workers, informal workers

Abstrak. Penelitian ini bertujuan untuk mengetahui perbedaan konflik peran ganda antara wanita pekerja formal dengan wanita pekerja informal, dan untuk memperoleh temuan tentang strategi coping pada wanita pekerja formal dan wanita pekerja informal dalam menghadapi konflik peran ganda. Metode yang digunakan dalam penelitian ini adalah studi deskriptif dengan pendekatan mix method. Pengambilan data dengan menggunakan Observasi dan wawancara. Hasil penelitian menunjukkan bahwa tidak ada perbedaan yang signifikan antara konflik peran ganda wanita pekerja formal dengan wanita pekerja informal. Konflik peran ganda pada wanita pekerja formal lebih tinggi daripada konflik peran ganda pada wanita pekerja informal. Strategi coping yang digunakan oleh wanita pekerja formal dalam bentuk Emotion Based diantaranya : kontrol emosi, menyesal karena terkadang kesal dengan anak-anak, pergi bersama keluarga, melampiaskan masalah dengan teman kerja. Bentuk problem based yang digunakan oleh wanita pekerja formal diantaranya: kontrol emosi, menyesal karena terkadang kesel dengan anak-anak, pergi bersama keluarga, melampiaskan masalah dengan teman kerja.

Kata kunci : Konflik, strategi coping, pekerja formal, pekerja informal

\section{PENDAHULUAN}

Sebagai makhluk sosial, manusia hidup secara berdampingan dan saling membutuhkan satu sama lain. Dalam skema hidup berdampingan inilah muncul kebutuhan untuk memahami kebutuhan manusia lainnya, sehingga timbullah hubungan antar manusia. Untuk memahami kebutuhan manusia khususnya keluarga (suami/istri, anak), manusia membutuhkan tanggung jawab dalam perannya sebagai pendidik dan sebagai pencari nafkah. Tetapi apabila tanggung 
jawab tersebut tidak dapt dipenuhi bisa menimbulkan konflik peran ganda.

Konflik peran ganda tersebut muncul karena adanya tekanan peran dari pekerjaan yang bertentangan dengan tekanan peran dari keluarga atau sebaliknya (Greenhaus dan Beutell, dalam Laksmi 2012). Konflik peran ganda terjadi ketika seorang individu menemukan bahwa patuh pada satu tuntutan peran menyebabkan dirinya kesulitan mematuhi tuntutan peran yang lain (Petronila, 2009). Konflik peran ganda yaitu konflik peran yang dialami dalam diri individu dalam hal hubungan dengan pasangan hidup, menjadi orang tua, dan mengurus rumah tangga atas adanya tekanan waktu, tuntutan pekerjaan, dan tuntutan keluarga dalam menjalankan peran pekerjaan dan keluarga secara bersamaan (Greenhaus dan Beutell, dalam Laksmi 2012). Tekanan yang muncul sebagai pencetus konflik peran ganda ini akan menganggu kinerja individu dalam melaksanakan perannya.

Pada dasarnya konflik peran ganda dapat terjadi baik pada pria maupun wanita. Meski demikian, beberapa penelitian menunjukkan bahwa intensitas terjadi konflik peran ganda pada wanita lebih besar dibandingkan pria (Apperson et al, 2002). Keterlibatan dan komitmen waktu perempuan pada keluarga yang didasari tanggung jawab mereka terhadap tugas rumah tangga, termasuk mengurus suami dan anak membuat para wanita bekerja lebih sering mengalami konflik (Simon, 1995 dalam Apperson et al, 2002)
Tingkat konflik ini lebih parah pada wanita yang bekerja secara formal dibandingkan dengan wanita yang bekerja secara informal, baik yang terikat dengan aturan tentang jam kerja, penugasan maupun target penyelesaian pekerjaan.

Sejalan dengan hasil penelitian Dwiyanti (2014) bahwa manajemen konflik pada wanita pekerja formal sebagian besar masih berada pada kategori cukup (45,45 \%), sedangkan manajemen konflik pada wanita pekerja informal sebagian besar berada pada kategori agak rendah $(40,91 \%)$, meskipun berdasarkan hasil penelitian tersebut juga di peroleh temuan bahwa tidak ada perbedaan manajemen konflik antara wanita pekerja formal dengan wanita pekerja Informal.

Studi oleh Apperson et al (2002) menemukan bahwa karakteristik pekerjaan yang sifatnya lebih formal dan manajerial seperti jam kerja yang relatif panjang dan pekerjaan yang berlimpah lebih cenderung memunculkan konflik peran ganda pada wanita bekerja.

Wanita yang bekerja di sektor formal cenderung memiliki tingkat pendidikan dan ketrampilan, akses ke lembaga keuangan, produktivitas tenaga kerja serta tingkat upah yang juga relatif lebih tinggi dibandingkan dengan wanita yang bekerja di sektor informal. Hal ini membuktikan bahwa tingkat intelektualitas wanita di sektor formal dituntut lebih karena pada dasarnya pekerjaan di sektor formal menuntut para pekerjanya untuk taat pada peraturan yang biasanya tertulis, pemberian sanksi apabila terjadi pelanggaran aturan, ada cuti yang dapat diambil, jam kerja yang jelas serta upah yang cenderung stabil atau diperoleh secara berkala. 
Sedangkan wanita yang bekerja di sektor informal cenderung memiliki tingkat pendidikan rendah. Menurut Gilarso (1992) bahwa sektor informal tidak hanya terdapat di perkotaan, melainkan juga di pedesaan, kegiatannya terutama di sektor perdagangan (penjual keliling, pedagang kaki lima, tukang loak, penjual buku bekas), sedang dari sektor jasa adalah tukang becak, buruh angkut, tukang gunting rambut dan sebagainya. Sektor informal disebut sebagai kegiatan ekonomi yang bersifat marjinal (kecil-kecilan) yang memperoleh beberapa ciri seperti kegiatan yang tidak teratur, tidak tersentuh peraturan, bermodal kecil dan bersifat harian, tempat tidak tetap berdiri sendiri, berlaku dikalangan masyarakat yang berpenghasilan rendah, tidak membutuhkan keahlian dan keterampilan khusus, lingkungan kecil atau keluarga serta tidak mengenal perbankan, pembukuan maupun perkreditan. Pekerjaan di sektor informal ini juga memiliki jam kerja yang relatif panjang dan tugas pekerjaan yang berlimpah, sehingga dapat memunculkan konflik peran ganda.

Greenhauss dan Beutell (dalam Almasitoh, 2011) menyatakan konflik peran ganda merupakan bentuk dari interrole conflict, dimana peran pekerjaan dan keluarga membutuhkan perhatian yang sama. Sebenarnya konflik dapat memiliki konsekuensi yang positif maupun negatif, tergantung bagaimana konflik tersebut dikelola. Sebagaimana yang dikemukakan Anoraga (2006), bahwa mengelola konflik merupakan kewajiban agar konflik yang ada tidak mempunyai konsekuensi yang negatif, tetapi konflik yang ada justru mempunyai konsekuensi yang positif bagi kelangsungan hidup suatu organisasi agar tetap bersaing dalam laju globalisasi.

Dalam budaya Banyumasan, menurut Herusatoto (2008), tingkah laku dan kebiasaan (Lageyan) orang banyumasan menunjukkan sifat seseorang atau komunitasnya. Gaya manajemen konflik pada wanita pekerja formal Banyumas, yaitu gaya manajemen konflik Bersaing, dalam budaya Banyumas merupakan ciri lagean ndopok, dablongan; adalah gaya manajemen konflik dengan kolaborasi, selain itu juga dengan gaya manajemen konflik yang menghindar, dalam budaya Banyumas merupakan ciri lagean cawag (Dwiyanti, 2015).

\begin{tabular}{llrr} 
& Karakter orang Banyumas \\
yang menonjol adalah suka & \multicolumn{2}{c}{ adara } \\
memberontak & terhadap & para \\
penguasa dan suka dan sering \\
terlibat di dalam konflik di_antara \\
mereka
\end{tabular}
Banyumas yang bersendikan bahasa dialek Banyumasan telah membangun budaya egaliter, yaitu mengakui kesepadanan antara anggota warganya (Priyadi, 2003).

Menghadapi konflik yang dialami, setiap manusia memiliki cara atau strategi sendiri dalam mengatasi konflik yang tidak bisa terlepas dari budaya setempat, karena setiap budaya memiliki tingkah laku dan kebiasaan yang berbeda-beda. Salah satu strategi dalam menghadapi konflik adalah coping yaitu respon individu untuk mengatasi masalah. Respon tersebut sesuai dengan apa yang dirasakan dan dipikirkan untuk mengontrol, mentolerir dan mengurangi efek negatif dari situasi yang dihadapi.

Perilaku coping merupakan suatu tingkah laku dimana individu melakukan interaksi dengan lingkungan sekitarnya dengan tujuan menyelesaikan tugas atau masalah 
(Chaplin, 2004). Terlebih pada masyarakat Jawa, karakter yang cukup khas adalah perilaku rukun dan hormat. Rukun diartikan sebagai keadaan selaras tanpa perselisihan dan pertentangan sedangkan hormat berarti kesadaran akan tempat dan tugas sehingga tercipta kesatuan yang selaras (Magnis dan Suseno, 2003). Upaya-upaya khusus, baik behavioral maupun psikologis, yang digunakan orang untuk menguasai, mentoleransi, mengurangi, atau meminimalkan dampak kejadian yang menimbulkan stress disebut sebagai strategi coping (MacArthur \& MacArthur ,1999).

\section{METODE PENELITIAN}

Metode Penelitian yang digunakan dapat diuraikan sebagai berikut :

\section{a. Subjek Penelitian}

Subjek penelitian ini adalah Wanita pekerja formal yaitu guru, pegawai pemerintahan, dan Wanita pekerja informal, yaitu Pedagang, yang bekerja di Purwokerto.

\section{b. Lokasi Penelitian :}

Lokasi penelitian dilakukan di Purwokerto karena masih banyak permasalahan tentang konflik pada wanita pekerja, dan permasalahan yang dialami wanita pekerja, sehingga perlu ada kajian tentang strategi coping wanita Banyumas dalam mengatasi konflik peran ganda.

\section{c. Metode Pengumpulan Data}

Metode penelitian ini menggunakan menggunakan kajian lapangan yaitu survai dengan menggunakan kombinasi pendekatan kualitatif dan kuantitatif. Untuk mengumpulkan data kuantitatif tentang konflik peran ganda akan dikumpulkan dengan skala konflik peran ganda. Sedangkan untuk pengumpulan data kualitatif tentang strategi coping wanita Banyumas dalam mengatasi konflik peran ganda, akan dikumpulkan dengan observasi, dan wawancara mendalam dengan pedoman wawancara yang dibuat peneliti.

\section{d. Analisis Data}

Untuk mengetahui gambaran tentang konflik peran ganda menggunakan analisis deskriptif kuantitatif dan teknik analisis t-test, sedangkan untuk strategi coping konflik peran ganda, analisis data dilakukan dengan pendekatan grounded theory yang terdiri dari tiga jenis coding, yaitu:

1) Open coding, yang merupakan proses mencermati data yang terkumpul. Hal ini dilakukan dengan cara mengurai, menelaah, mengartikan, membanding - kan dan mengkategorisasikan data yang dianalisis. Fenomena yang dikategorikan diteliti melalui penelaahan yang teliti dan detil. Hasil akhir yang didapatkan adalah kategori-kategori umum yang mampu mereprentasikan sebanyak mungkin gejala atau fenomena yang diteliti. Kategorikategori ini harus dapat diurai secara rinci ciri-cirinya (property), dimensi besarannya (dimension), contoh nyatanya (example).

2) Axial coding, merupakan satu proses yang diarahkan untuk mengintegrasikan data yang telah dianalisis melalui open coding sehingga terlihat keterkaitan antara kategori-kategori yang dihasilkan dalam open coding. Dianalisis untuk dilihat pola interelasinya, diidentifikasi 
kemungkinan-kemungkinan

hubungan sebab akibatnya, serta dianalisis pula faktor-faktor yang berhubungan dengan konteks, intervening conditions, interaksi antar faktor, serta konsekuensinya. Jadi, hasil akhir dari proses ini adalah ditemukannya proposisi yang menggambarkan dinamika hubungan antar kategori untuk kemudian duji validitasnya.

3) Selective coding, yakni proses pemilihan kategori pokok kemudian secara sistematis menghubungkannya dengan kategori-kategori yang lain.

Proses ini secara langsung akan memvalidasi keterkaitan antara kategori-kategori pokok lewat rekonseptualisasi menghasilkan satu cerita atau narasi. Narasi ini diarahkan untuk menggambarkan dan menjelaskan dinamika fenomena utama yang menjadi fokus penelitian dalam satu bentuk yang integratif.

\section{HASIL DAN PEMBAHASAN}

\section{a. Deskripsi Data Konflik Peran Ganda}

Deskripsi data konflik peran ganda pada subjek penelitian adalah sebagai berikut :

1) Deskripsi data konflik peran ganda wanita pekerja formal

Tabel 1.

Distribusi Frekuensi skor Konflik Peran Ganda Wanita Pekerja Formal

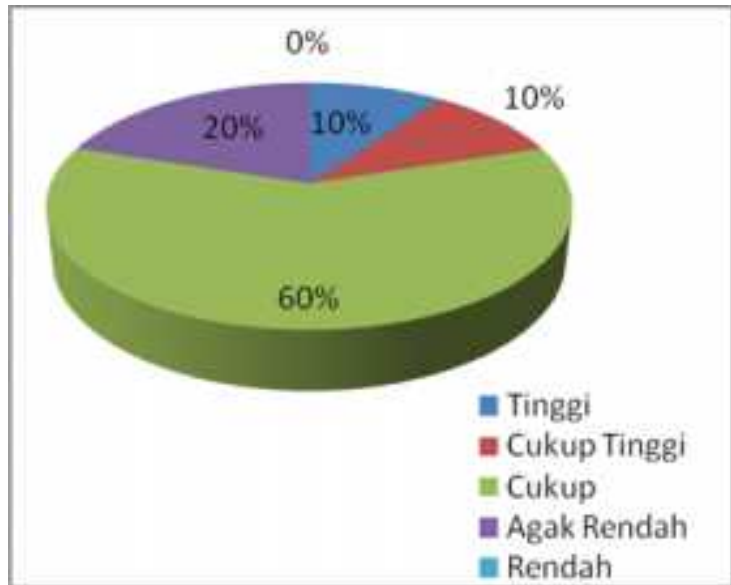

\section{Gambar 1. Data Konflik Peran Ganda Wanita Pekerja Formal}

Berdasarkan hasil penelitian yang telah dilakukan menunjukkan bahwa dari 20 wanita pekerja formal : 2 orang (10\%) menunjukkan konflik peran ganda pada kategori tinggi, 2 orang (10\%) menunjukkan konflik peran ganda cukup tinggi, 12 orang $(60 \%)$ menunjukkan konflik peran ganda pada kategori cukup, 4 orang $(20 \%)$ menunjukkan konflik peran ganda pada kategori agak rendah, dan tidak ada satupun $(0 \%)$ wanita pekerja formal yang menunjukkan konflik peran ganda pada kategori rendah. 
Distribusi Frekuensi skor Konflik Peran Ganda Wanita Pekerja Formal

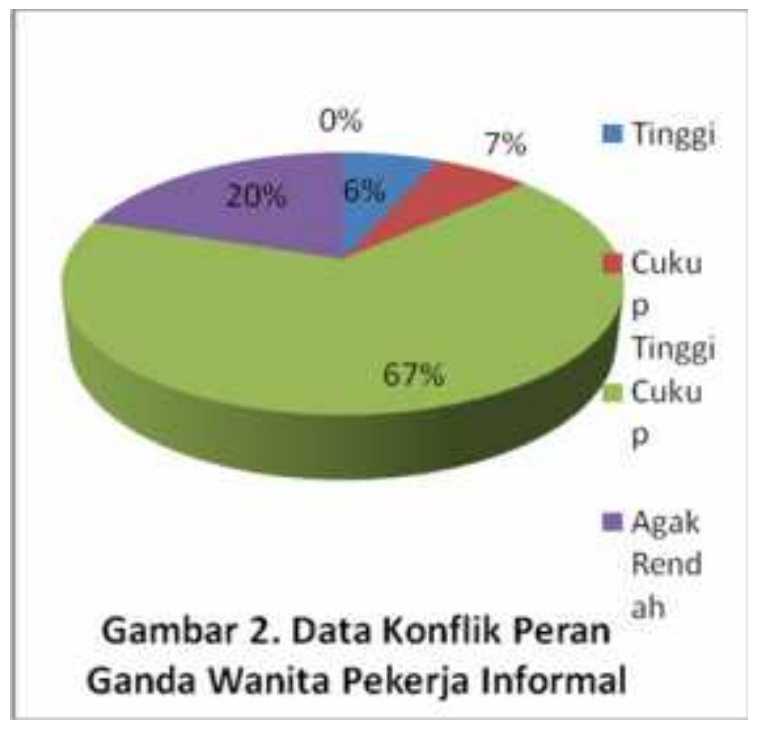

Berdasarkan hasil penelitian yang telah dilakukan menunjukkan bahwa dari 15 wanita pekerja informal : 1 orang $(6,7 \%)$ menunjukkan konflik peran ganda pada kategori tinggi, 1 orang $(6,7 \%)$ menunjukkan konflik peran ganda cukup tinggi, 10 orang $(66,6 \%)$ menunjukkan konflik peran ganda pada kategori cukup, 3 orang (20\%) menunjukkan konflik peran ganda pada kategori agak rendah, dan tidak ada satupun (0\%) wanita pekerja informal yang menunjukkan konflik peran ganda pada kategori rendah.

Hasil tersebut menunjukkan bahwa pada wanita pekerja formal maupun wanita pekerja informal memiliki konflik peran ganda pada kategori cukup, dan ada 6 subjek yang memiliki konflik peran ganda pada kategori cukup tinggi. Menurut Greenhaus dan Beutell (dalam Laksmi, 2012), konflik peran ganda didefinisikan sebagai suatu bentuk konflik peran dalam diri seseorang yang muncul karena adanya tekanan peran dari pekerjaan yang bertentangan dengan tekanan peran dari keluarga. Konflik peran ganda bisa terjadi akibat lamanya jam kerja seseorang, sehingga waktu bersama keluarga menjadi kurang. Individu harus menjalankan dua peran secara bersamaan, yakni dalam pekerjaan dan dalam keluarga sehingga faktor emosi dalam satu wilayah menganggu wilayah lainnya.

\section{b. Perbedaan Konflik Peran Ganda Wanita Pekerja Formal dengan Wanita Pekerja Informal}

Untuk mengetahui perbedaan antara konflik peran ganda wanita pekerja formal dengan wanita pekerja informal, dilakukan analisis uji beda ( $\mathrm{t}-$ test). Berdasarkan hasil analisis diperoleh t-test sebesar 0,79 dan $t_{\text {tabel }}$ $=2,750$ dengan taraf signifikansi sebesar 0,01. Hasil tersebut menunjukan bahwa t-test $<t_{\text {tabel, }}$ artinya tidak ada perbedaan yang signifikan antara konflik peran ganda wanita pekerja formal dengan wanita pekerja informal. Berdasarkan nilai rata-ratanya diperoleh $M_{1}$ sebesar 
86,3 dan $M_{2}$ sebesar 82,4 , hal ini bahwa konflik peran ganda pada wanita pekerja formal lebih besar

c. Penyebab Konflik Peran Ganda menunjukan

daripada konflik peran ganda pada wanita pekerja informal.

Berdasarkan hasil wawancara diperoleh temuan sebagai berikut :

Tabel 3. Penyebab Konflik Peran ganda

\begin{tabular}{|c|c|c|c|}
\hline \multirow{2}{*}{ No } & \multirow{2}{*}{ Subjek } & \multicolumn{2}{|l|}{ Strategi Coping } \\
\hline & & Dari Keluarga & Dari Pekerjaan \\
\hline \multicolumn{4}{|c|}{$\begin{array}{l}\text { Pekerja } \\
\text { Formal }\end{array}$} \\
\hline 1 & WN & $\begin{array}{l}\text { 1. Masalah dengan suami } \\
\text { 2. Pembantu terkadang tidak } \\
\text { datang } \\
\text { 3. Perbedaan pendapat } \\
\text { dengan mertua }\end{array}$ & $\begin{array}{l}\text { 1. Tidak ada masalah dalam } \\
\text { pekerjaan }\end{array}$ \\
\hline 2 & HR & $\begin{array}{l}\text { 1. Masalah keuangan } \\
\text { 2. Pendapatan suami lebih } \\
\text { kecil } \\
\text { 3. Menanggung kehidupan } \\
\text { keluarga }\end{array}$ & $\begin{array}{l}\text { 1. Bekerja sampai larut } \\
\text { malam } \\
\text { 2. Kesulitan membagi waktu }\end{array}$ \\
\hline \multicolumn{4}{|c|}{$\begin{array}{l}\text { Pekerja } \\
\text { informal }\end{array}$} \\
\hline 3 & MA & $\begin{array}{l}\text { 1. Perbedaan pendapat } \\
\text { dengan suami } \\
\text { 2. Kesulitan meluangkan } \\
\text { waktu dengan keluarga }\end{array}$ & 1. Hari libur tetap berjualan \\
\hline 4 & $\mathrm{Al}$ & $\begin{array}{l}\text { 1. Kesulitan meluangkan } \\
\text { waktu dengan keluarga }\end{array}$ & $\begin{array}{l}\text { 1. Berjualan dari pagi } \\
\text { sampai sore }\end{array}$ \\
\hline
\end{tabular}

\section{d. Strategi Coping Wanita Pekerja Formal dan Informal}

Berdasarkan hasil wawancara diperoleh temuan sebagai berikut :

Tabel 4. Strategi coping wanita pekerja 


\begin{tabular}{|c|c|c|c|}
\hline \multirow{2}{*}{ No } & \multirow{2}{*}{ Subjek } & \multicolumn{2}{|l|}{ Strategi Coping } \\
\hline & & Emotion Based & Problem Based \\
\hline \multicolumn{4}{|c|}{$\begin{array}{l}\text { Pekerja } \\
\text { Formal }\end{array}$} \\
\hline 1 & WN & $\begin{array}{l}\text { 1. Kontrol emosi } \\
\text { 2. Menyesal karena } \\
\text { terkadang kesel dengan } \\
\text { anak-anak }\end{array}$ & $\begin{array}{l}\text { 1. Bagi tugas dengan suami } \\
\text { 2. Dibantu oleh pembantu } \\
\text { rumah tangga } \\
\text { 3. Mengatur waktu kerja dan } \\
\text { keluarga }\end{array}$ \\
\hline 2 & $\mathrm{HR}$ & $\begin{array}{l}\text { 1. Pergi bersama keluarga } \\
\text { 2. Melampiaskan masalah } \\
\text { dengan teman kerja }\end{array}$ & $\begin{array}{l}\text { 1. Anak ditipkan pada orang } \\
\text { tua } \\
\text { 2. Menjalin hubungan yang } \\
\text { baik dengan anak-anak } \\
\text { 3. Suami mengambil cuti } \\
\text { 4. Mengerti satu sama lain }\end{array}$ \\
\hline \multicolumn{4}{|c|}{$\begin{array}{l}\text { Pekerja } \\
\text { informal }\end{array}$} \\
\hline 3 & MA & $\begin{array}{l}\text { 1. Meluangkan waktu } \\
\text { dengan keluarga } \\
\text { 2. Liburan } \\
\text { 3. Rutin mengikuti } \\
\text { pengajian }\end{array}$ & $\begin{array}{l}\text { 1. Dukungan dari suami } \\
\text { 2. Memperbanyak waktu } \\
\text { bersama anak }\end{array}$ \\
\hline 4 & $\mathrm{Al}$ & $\begin{array}{l}\text { 1. Bercanda dengan anak- } \\
\text { anak } \\
\text { 2. Jalan-jalan keluar makan } \\
\text { bersama } \\
\text { 3. Menjalankan sholat }\end{array}$ & $\begin{array}{l}\text { 2. Meminta suami } \\
\text { membantu mengurus } \\
\text { anak } \\
\text { 3. melibatkan anak yang } \\
\text { sudah besar dalam } \\
\text { mengurus anak }\end{array}$ \\
\hline
\end{tabular}

Berdasarkan hasil analisis uji beda diperoleh t-test sebesar 0,79 dan $t_{\text {tabel }}=2,750$ dengan taraf signifikansi sebesar 0,01. Hasil tersebut menunjukan bahwa t-test $<t_{\text {tabel}}$, artinya tidak ada perbedaan yang signifikan antara konflik peran ganda wanita pekerja formal dengan wanita pekerja informal. Hal ini sejalan dengan hasil wawancara dari wanita pekerja formal, bahwa penyebab konflik peran ganda diantaranya adalah permasalahan yang berhubungan dengan suami, ketidakhadiran pembantu, dan masalah keuangan keluarga. Sedangkan penyebab munculnya konflik wanita pekerja informal, yang menjadi penyebab munculnya konflik adalah kesulitan meluangkan waktu dengan keluarga. Menurut Sekaran (dalam Almasitoh, 2011) ada beberapa hal yang menyebabkan terjadinya konflik peran ganda, yaitu pengasuhan anak dan bantuan pekerjaan rumah tangga, komunikasi dan interaksi dengan keluarga, waktu untuk keluarga, penentuan prioritas sebagai seorang istri, dan tekanan karir dan keluarga. 
Berdasarkan nilai rata-ratanya diperoleh $M_{1}$ sebesar 86,3 dan $M_{2}$ sebesar 82,4, hal ini menunjukan bahwa konflik peran ganda pada wanita pekerja formal lebih besar daripada konflik peran ganda pada wanita pekerja informal. Keterlibatan dan komitmen waktu perempuan pada keluarga yang didasari tanggung jawab mereka terhadap tugas rumahtangga, termasuk mengurus suami dan anak membuat para wanita bekerja lebih sering mengalami konflik (Simon, dalam Apperson et al, 2002) Tingkat konflik ini lebih parah pada wanita yang bekerja baik secara formal maupun informal yang terikat dengan aturan tentang jam kerja, penugasan atau target penyelesaian pekerjaan.

Apperson et al (2002) menemukan bahwa karakteristik pekerjaan yang sifatnya lebih formal dan manajerial seperti jam kerja yang relatif__panjang dan pekerjaan yang berlimpah lebih cenderung memunculkan konflik peran ganda pada wanita bekerja. Namun demikian pekerjaan yang bersifat informal juga rentan terhadap konflik peran ganda.

Wanita yang bekerja di sektor formal memiliki tingkat pendidikan dan ketrampilan, memiliki fleksibilitas dengan lembaga keuangan, memiliki produktivitas yang lebih tinggi serta tingkat upah yang juga relatif lebih tinggi dibandingkan dengan wanita yang bekerja di sektor informal. Hal ini membuktikan bahwa tingkat intelektualitas wanita di sektor formal dituntut lebih karena pada dasarnya pekerjaan di sektor formal menuntut para pekerjanya untuk taat pada peraturan yang biasanya tertulis, pemberian sanksi apabila terjadi pelanggaran aturan, ada cuti yang dapat diambil, jam kerja yang jelas serta upah yang cenderung stabil atau diperoleh secara berkala. Menurut Greenhaus dan Beutell, dalam Laksmi (2012). Konflik peran ganda tersebut muncul karena adanya tekanan peran dari pekerjaan yang bertentangan dengan tekanan peran dari keluarga atau sebaliknya.

Berdasarkan data keempat subjek tersebut, dapat diidentifikasi bahwa kesemuanya melakukan strategi coping tertentu untuk mengatasi konflik peran ganda yang dihadapi. Strategi yang dipilih setiap subjek merupakan kombinasi dari problem focused coping dan emotion focused coping, yang dilakukan secara pribadi (solitary coping) maupun dengan melibatkan orang lain (social coping). Bentuk problem focused coping antara lain adalah mempekerjakan pekerja rumah tangga dan/ atau meminta bantuan anggota keluarga (suami, mertua) untuk membantu mengasuh anak, merencanakan waktu keluarga bersama-sama anggota keluarga lain,

Sedangkan bentuk emotion based coping adalah dengan memahami perbedaan dalam berinteraksi dengan anggota keluarga dan melampiaskan masalah dengan rekan sekerja, beribadah lebih tekun, mengekspresikan kesedihan, berbagi cerita Lazarus dan Folkman (1984) mengungkapkan terjadinya perbedaan tersebut sangat tergantung pada kepribadian seseorang dan sumber stress yang dihadapinya. Individu akan cenderung lebih banyak menggunakan pendekatan problem focused bila mereka meyakini bahwa sumber daya atau tuntutan yang dihadapi akan berubah, sedangkan 
bila individu meyakini tidak dapat melakukan apa-apa maka untuk mengubah kondisi stress digunakan emotion focused. Coping yang dilakukan responden wanita bekerja dalam penelitian ini sebagian besar masih merupakan bentuk intervensi pada level individu dan keluarga serta belum banyak intervensi organisasional yang sifatnya nyata.

\section{SIMPULAN}

Deskripsi data konflik peran ganda menunjukkan bahwa dari 20 wanita pekerja formal : 2 orang (10 \%) menunjukkan konflik peran ganda pada kategori tinggi, 2 orang $(10 \%)$ menunjukkan konflik peran ganda cukup tinggi, 12 orang $(60 \%)$ menunjukkan konflik peran ganda pada kategori cukup, 4 orang $(20 \%)$ menunjukkan konflik peran ganda pada kategori agak rendah. Sedangkan pada wanita pekerja informal : $\quad 1$ orang $(6,7 \%)$ menunjukkan konflik peran ganda pada kategori tinggi, 1 orang $(6,7 \%)$ menunjukkan konflik peran ganda cukup tinggi, 10 orang (66,6\%) menunjukkan konflik peran ganda pada kategori cukup, 3 orang $(20 \%)$ menunjukkan konflik peran ganda pada kategori agak rendah. Berdasarkan hasil uji beda tidak ada perbedaan yang signifikan antara konflik peran ganda wanita pekerja formal dengan wanita pekerja informal. Konflik peran ganda pada wanita pekerja formal lebih besar daripada konflik peran ganda pada wanita pekerja informal. Strategi coping yang digunakan oleh wanita pekerja formal dalam bentuk Emotion Based diantaranya : kontrol emosi, menyesal karena terkadang kesal dengan anak-anak, pergi bersama keluarga, melampiaskan masalah dengan teman kerja, dan dalam bentuk problem based diantaranya: kontrol emosi, menyesal karena terkadang kesel dengan anak-anak, pergi bersama keluarga, melampiaskan masalah dengan teman kerja. 


\section{DAFTAR PUSTAKA}

Almasitoh, U.H. 2011. Stress Kerja Ditinjau Dari Konflik Peran Ganda Dan Dukungan Social Pada Perawat. PSIKOISLAMKA, Jurnal psikologi islami (JPI) Vol.8 No.01 tahun 2011:hal 68-82. Didownload pada tanggal 4 Desember 2012

Anoraga, P., 2006. Psikologi Kerja. Jakarta : PT Rineka Cipta.

Apperson et al. 2002. "Women Managers and the Experience of Work-Family Conflict". American Journal of Undergraduate Research. Vol.1. No.3.

Chaplin, J.P. 2004. Kamus Lengkap Psikologi, (Terjemahan Kartini dan Kartono). Jakarta: Raja Grafindo Persada.

Dwiyanti .2014. Dwiyanti. 2014. Perbedaan Manajemen Konflik Antara Wanita Pekeria Formal Dengan Wanita Pekeria Informal Di Purwokerto. Prosiding Seminar Nasional LPPM. Universitas Muhammadiyah Purwokerto

2015. Studi Tentang Gaya Manajemen Konflik Dengan Pendekatan Budaya Banyumasan Pada Wanita Pekerja Formal Di Purwokerto. Penelitian Hibah Kompetitif. Universitas Muhammadiyah Purwokerto

Gilarso, T. 1992. Pengantar IImu Ekonomi Bagian Makro. Yogyakarta: Kanisius

Herusatoto 2008. Banyumas : sejarah, budaya dan watak. Yogyakarta : LKiS

Laksmi, N.A.P \& Hadi, C. 2012. Hubungan Antara Konflik Peran Ganda (Work Family Conflict) dengan Kepuasan Kerja Pada Karyawati Bagian Produksi PT.X. Jurnal Psikologi Industri \& Organisasi Vol.1 No. 02., Juni 2012.

Lazarus, R.S., \& Folkman, S. 1984. Stress, Appraisal, and Coping. New York : Springer Publishing Company

Magnis dan Suseno F, 2003. Etika Dasar masalah-masalah pokok Filsafat Moral. Yogyakarta : penerbit Kanisius

Petronila, T.A., Tjendra, V \& Hartiningsih, L. 2009. Pengaruh Komitmen Organisasi, Konflik Peran Terhadap Turnover Intension Dengan Kepuasan Kerja. Jurnal Akuntabilitas Vol.8 No.02 tahun 2009

Priyadi,S 2003. Beberapa Karakter orang Banyumas. Jurnal Bahasa dan seni, tahun 31, nomor 1. 